OPEN ACCESS

Edited by:

Elif Kongar,

University of Bridgeport, United States

Reviewed by:

Julie Woods,

Deakin University, Australia

Kurt A. Rosentrater

lowa State University, United States

Albert Thembinkosi Modi,

University of KwaZulu-Natal,

South Africa

${ }^{*}$ Correspondence:

Len F. Marquart

Imarquar@umn.edu

Specialty section

This article was submitted to Nutrition and Sustainable Diets,

a section of the journal

Frontiers in Sustainable Food Systems

Received: 25 October 2019

Accepted: 27 April 2020

Published: 22 May 2020

Citation:

Ringling KM and Marquart LF (2020)

Intersection of Diet, Health, and

Environment: Land Grant Universities'

Role in Creating Platforms for

Sustainable Food Systems.

Front. Sustain. Food Syst. 4:70.

doi: 10.3389/fsufs. 2020.00070

\section{Intersection of Diet, Health, and Environment: Land Grant Universities' Role in Creating Platforms for Sustainable Food Systems}

\author{
Keagan M. Ringling and Len F. Marquart* \\ Department of Food Science and Nutrition, University of Minnesota, St. Paul, MN, United States
}

Food and agriculture professionals strive to feed the growing population diets that maintain human health and minimize environmental impacts. Recently, global organizations such as the World Health Organization and the Food and Agricultural Organization have set goals related to the sustainable production of nutritious foods. In this vein, the EAT-Lancet Commission on Food, Planet, and Health has set dietary recommendations for human and planetary health. These recommendations, based on a wide body of evidence, suggest that plant-based diets are essential for the persistence of the population and the environment. This article briefly reviews the influence of diets on health and environmental outcomes in the context of the EAT-Lancet recommendations. Then the brief discusses the role of land grant universities in developing nutrition sensitive, environmentally resilient food systems. Then the article discusses local food system initiatives in Minnesota and offers insight into how the University of Minnesota may play a role in developing nutrition sensitive value chains by coordinating and supporting local food efforts. Ultimately, this brief suggests that land grant universities can help local communities equitably collaborate with upstream and downstream value chain actors to develop nutrition sensitive, environmentally resilient value chains.

Keywords: nutrition, value chain, environment, diet, sustainability, agriculture

\section{INTRODUCTION}

Food system professionals must feed a growing global population healthful, environmentally resilient diets (Clark et al., 2018).The global food system contributes to the triple burden of hunger, micronutrient deficiency, and obesity (Gomez and Barrett, 2013). Meanwhile, poor food production practices contribute to environmental degradation through greenhouse gas emissions, soil erosion, and decreased biodiversity. The negative implications of this system may exacerbate as the population surpasses 9 billion by 2,050, and food production increases to meet demand (Tilman et al., 2011). Recognizing this wicked challenge, the World Health Organization (WHO) and the Food and Agriculture Organization (FAO) developed 17 cross-cutting Sustainable Development Goals that promote human and environmental health (FAO., 2017a). These goals provide orientation and direction for local food systems to achieve diets that support human and environmental health. 
Local food systems are increasingly important as consumers demand transparent, equitable food systems (Wognum et al., 2011). Many efforts strive to improve agricultural sustainability; provide equitable, culturally appropriate access to safe, nutritional foods; and enhance economies. Despite inextricable linkages, these efforts often occur in isolation. Enhanced coordination of local efforts focusing on agriculture, nutritional food security, and economic development could conceivably yield major impacts on human health, environmental sustainability and economic prosperity. Land grant universities provide a platform for enhanced coordination of these efforts while operating at the nexus of the public and private sectors (Korczak et al., 2015). These universities were established to provide a practical education of agricultural, mechanical, and classical studies to the public using federal land (Association of Public and Land-Grant Universities Association of Public Land-Grant Universities [APLU]., 2012). Faculty, students, research platforms, agriculture experiment stations, and extension services (e.g., community outreach) are key components of this mission (Association of Public and Land-Grant Universities Association of Public Land-Grant Universities [APLU]., 2012). Universities play a crucial role in generating research and engaging in outreach activities that assist local efforts to improve agricultural sustainability and to provide equitable access to healthful foods.

Here, we briefly discuss links between diets and environment by highlighting information published by the EAT-Lancet Commission on Food, Planet, and Health (EAT-Lancet) to provide a global context. We discuss the potential role of land grant universities in supporting the development of nutrition sensitive food systems. The article then describes Minnesota-based initiatives providing healthful, affordable, safe foods for communities as an example of local efforts linking community, university, and industry activities. Finally, the article recommends that the University of Minnesota can play a role in developing nutrition sensitive value chains.

\section{PART 1 - DIET, HEALTH, AND ENVIRONMENT: GLOBAL CONTEXT AND RECOMMENDATIONS}

Sustainable diets promote health and nutrition, minimize environmental impacts, remain economically feasible, and promote sociocultural wellness (Drewnowski, 2018). Healthful diets include adequate amounts of protein-rich foods, fruits, vegetables, and fats. Dietary recommendations vary depending on demographic characteristics. However, dietary guidance, such as the Dietary Guidelines for Americans (DGAs), is based on mean population requirements (Obama, 2019). The DGA-recommended dietary pattern should support the health of the general population, but achieving dietary guidance is difficult as the food supply is largely non-compliant with DGAs (Krebs-Smith et al., 2010; Miller et al., 2015). Dietary guidance has not traditionally accounted for the impact of diets on the environment, which presents an opportunity as we approach 2050.
A growing body of literature highlights the link between plant-based diets, nutrition, and environmental health. The EATLancet report suggests diets promoting nutrition and physical health as well as environmental sustainability are essential for the persistence of the global population (Willett et al., 2019). Plant-based diets are associated with decreased mortality and decreased risk for chronic disease (Orlich et al., 2013; Satija et al., 2016, 2017). Increased vegetable and fruit consumption is associated with decreased risk for chronic diseases (Hung et al., 2004), including Type 2 Diabetes mellitus (T2DM) (Muraki et al., 2013), cardiovascular disease (CVD), cancer (Aune et al., 2017), and weight gain (Bertoia et al., 2015). Diets rich in whole grains are associated with decreased risk for T2DM, CVD, and cancer (Parker et al., 2013; Aune et al., 2016a). Similarly, nut and legume consumption is associated with decreased risks of CVD, T2DM, and all-cause mortality (Bernstein et al., 2010; Afshin et al., 2014; Aune et al., 2016b). This contrasts with diets high in animal-based foods, particularly red processed meats, which are associated with increased risk for chronic disease (Pan et al., 2012; Chen et al., 2013; Feskens et al., 2013). Other studies indicate that plant-based diets have a reduced carbon footprint compared to diets high in animal-derived foods. A 2017 analysis showed that consumption and production of fruits, vegetables, and grains have lower impacts on global warming via decreased greenhouse gas emissions compared to red meat (Clune et al., 2017). This supports a 2017 study assessing environmental impacts of agricultural production systems and food choice, which showed that animal-derived foods have a negative environmental impact compared to plant-based foods (Clark and Tilman, 2017). Other reports show clear links between dietary patterns and environmental impacts, with plant-based diets having considerably reduced impacts compared to those that include meat (US Department of Agriculture and US Department of Health and Human Services, 2000; Hallström et al., 2015; Aleksandrowicz et al., 2016; Nelson et al., 2016).

The parallel benefits of plant-based diets for human and environmental health may influence future dietary recommendations, as shown by the EAT-Lancet report (Willett et al., 2019). The report recommends a diet low in animalderived foods like red meat and dairy and encourages increased vegetable, fruit, legume, and whole grain consumption (Willett et al., 2019). This is similar to the DASH and Mediterranean diets, which purportedly have lower environmental impacts compared to Western diets (Nelson et al., 2016). While this diet would likely improve human health and reduce greenhouse gas emissions, some question its one-size-fits-all nature. The WHO withdrew support due to questions around the feasibility and cultural suitability of the diet ${ }^{1}$. The cultural significance of food and agriculture is largely absent from the report. Future iterations might benefit by incorporating inclusive, socio-cultural perspectives. Despite these limitations, EAT-Lancet provides evidence-driven insight into the influence of sustainable diets and sets goals for food systems professionals.

\footnotetext{
${ }^{1}$ WHO Withdraws Endorsement of EAT-Lancet Diet. Nutritioninsight.com/ (2019). Available online at: https://ni.cnsmedia.com/a/HBn6DJkUnv4= (accessed July 6, 2019).
} 
Developing foods and diets that sustain planetary and human health requires multiple disciplinary, systems approaches that account for nutrition, food science, agriculture, ecology, economics, policy, and socio-cultural factors (Barbier and Burgess, 2017; Tu et al., 2019). Systems approaches are becoming critical in addressing complex societal issues like obesity (Huang et al., 2009) and conservation agriculture policy (Ribeiro et al., 2016). However, these approaches are often difficult to conceive and coordinate due to their large size and broad scope. Land grant universities could play a critical role in implementing and training the next generation of professionals to use these approaches.

\section{PART 2 - THE ROLE OF LAND GRANT UNIVERSITIES IN DEVELOPING NUTRITION SENSITIVE FOOD SYSTEMS}

Land grant universities can play a leading role in using food systems frameworks to assess the agronomic, economic, public health, and sociocultural aspects of sustainable diets. For example, in cooperation with on-campus faculty and outreach centers, agricultural experiment stations can research the ecological implications of planting crops that support recommended dietary patterns. Concomitant applied economic studies can evaluate the economic feasibility of agricultural changes (Boland et al., 2016). From a community perspective, university-led studies might assess public health and socioeconomic impacts of populations adapting to sustainable dietary guidance. University extension programs may assess cultural appropriateness of dietary recommendations (Hassel, 2014; Hassel et al., 2019). Overall, these data might help food systems actors create comprehensive, holistic strategies to develop sustainable, healthful, economically feasible food systems.

There are barriers to enacting this type of approach. Despite the interlinked nature of our food system, academic research and training remains largely siloed. Research activities occur in a segmented, disciplinarily isolated manner, and institutional practices may directly inhibit the ability to cross disciplinary boundaries (Choi and Pak, 2007). Other institutional factors, like the tenure process and faculty recognition, are often predicated on single disciplinary approaches, which make it difficult to collaborate outside of a discipline (Weaver, 2008). Food systems approaches require researchers and partners to overcome this traditional paradigm, perhaps by structuring institutional processes to offer merit for multiple disciplinary, systems approaches, particularly for young faculty.

Translating university research to practical application in community settings can be difficult. The complexity of health issues in diverse communities can hinder traditional research approaches (Minkler, 2005; Graham et al., 2006). These approaches are often limited by a lack of consideration for diverse sociocultural perspectives, which can reduce community acceptance (Hassel, 2014; Hassel et al., 2019). Communitybased participatory action research (CBPAR), which integrates community stakeholders into project design and execution, may improve translation of research to practical application
(Wallerstein and Duran, 2010). These approaches are reciprocal in nature and allow communities to take agency in driving research initiatives, which may improve outcomes compared to traditional interventions.

Other sectors adapting systems models may provide examples for the food sector. For instance, like the food system, healthcare is non-linear, dynamic, and unpredictable (Lipsitz, 2012). As a result, the medical sector has implemented systems models for research and training (Choi and Pak, 2006, 2007; Weaver, 2008). Some models emphasize multiple-disciplinary training and research, systems thinking, cross-cultural engagement, and professional skill (e.g., communication, collaboration, critical thinking, leadership, etc.) development (Sehgal et al., 2008; Stroud et al., 2017). The medical sector has also implemented CBPAR approaches to address health disparities in at-risk communities (Wallerstein and Duran, 2006; Campbell, 2010). Some STEM fields also integrate systems thinking into training programs (Fowler et al., 2019). Training the next generation in these approaches may improve land grant universities' impacts on food systems. Despite these challenges and limitations, many universities are pursuing integrative research and training approaches, with some highlighting the need for a future workforce of food systems analysts (Ingram et al., 2020). Therefore, it is important to contextualize and describe local food systems efforts. The University has a potential role to engage with local groups to develop more nutrition-sensitive food systems.

\section{PART 3 - LOCAL CONTEXT - MINNESOTA FOOD SECURITY: SUPPLY CHAIN FIRMS AND INFLUENCERS}

Agriculture and food production are critical to the Minnesota economy. In 2019, Minnesota agricultural production was valued at over $\$ 17$ billion, making it the 5th largest agricultural state (Ye, 2019). Minnesota also hosts the headquarters of many multinational food companies, including General Mills, Cargill, Supervalu, Land O'Lakes, and Hormel (Table 1) ${ }^{2}$. The state also boasts many small to medium size food and beverage companies.

Despite a thriving agriculture and food sector, many Minnesotans remain food insecure. According to a 2016 study, Minnesota is 7th worst in the nation for access to healthful foods (Rausch et al., 2016). Food security impacts nearly $10 \%$ of Minnesota families due to many contributing factors including income, transportation, and difficulty to access benefits, like Supplemental Nutrition Assistance Program and the Women Infant and Children program (Minnesota Department of Health, 2019a,b; Minnesota Department of Health, 2019a; Minnesota Department of Health, 2019b). Access to nutritional foods is largely tied to socioeconomic status. In 2017, the Center for Disease Control found that prevalence of obesity increased in US adults as income and education levels decreased (Ogden et al., 2017). This may be due to the decreased costs associated with energy dense, high sugar foods compared to nutrient-rich

${ }^{2}$ Minnesota Department of Employment and Economic Development. Minnesota’s food and beverage industries. p. 2. 
TABLE 1 | Recommendation of value chain actors, influencers, and roles in Minnesota.

\begin{tabular}{|c|c|}
\hline \multicolumn{2}{|c|}{ Minnesota value chain actors, influencers, and roles } \\
\hline Entity & Role \\
\hline Farmers & Crop production \\
\hline $\mathrm{CHS}$ & Agriculture, co-operative \\
\hline Cargill & Agriculture, processing \\
\hline Land O'Lakes & Agriculture, processing \\
\hline General Mills & Food processing \\
\hline Hormel & Food processing \\
\hline August schell brewing company & Brewing \\
\hline Surly brewing & Brewing \\
\hline Bay state milling company & Milling, ingredient manufacturing \\
\hline Grain millers & Milling, ingredient manufacturing \\
\hline Calyxt & Crop development \\
\hline Supervalu & Wholesaling and retailing \\
\hline Target & Retailing \\
\hline $\begin{array}{l}\text { University of Minnesota college of food, } \\
\text { agriculture, and natural resource science }\end{array}$ & $\begin{array}{l}\text { Training, research: agronomy, food } \\
\text { science, nutrition, ecology }\end{array}$ \\
\hline $\begin{array}{l}\text { University of Minnesota school of public } \\
\text { health }\end{array}$ & $\begin{array}{l}\text { Training, research: nutrition and health } \\
\text { epidemiology }\end{array}$ \\
\hline $\begin{array}{l}\text { University of Minnesota college of } \\
\text { veterinary medicine }\end{array}$ & $\begin{array}{l}\text { Training, research: food safety, animal } \\
\text { health }\end{array}$ \\
\hline University of Minnesota medical school & Training, research: health \\
\hline $\begin{array}{l}\text { Regional sustainable development } \\
\text { partnerships }\end{array}$ & Extension, outreach \\
\hline Forever green initiative & Crop development \\
\hline Grow North MN & Agriculture and food entrepreneurship \\
\hline Second harvest Heartland & Food bank, aggregation, distribution \\
\hline Good Acre & $\begin{array}{l}\text { Food hub, community engagement: } \\
\text { agriculture and culinary programs }\end{array}$ \\
\hline Dream of wild health & $\begin{array}{l}\text { Food sovereignty and Indigenous } \\
\text { knowledge systems }\end{array}$ \\
\hline Seeds of native health & $\begin{array}{l}\text { Food sovereignty and Indigenous } \\
\text { knowledge systems }\end{array}$ \\
\hline
\end{tabular}

This is a non-comprehensive overview.

foods (Andrieu et al., 2006; Monsivais and Drewnowsky, 2010). Disproportionate access to high-calorie, low-nutrient-dense foods may contribute to prevalence of obesity in Minnesota. Over $60 \%$ of Minnesota adults are overweight, and $30 \%$ are obese, resulting in $\$ 3$ billion in healthcare expenditure (Minnesota Department of Health, 2019b).

Food supply chains determine critical factors that influence diet and food choice, including price, availability, convenience, and safety. Supply chains include all actors and processes from production to consumption. As raw materials flow through the chain, key steps add value to the product, which gives rise to the term "value chain" (Figure 1). While the traditional value chain concept focuses solely on economic value, there is burgeoning interest in the concept of nutrition sensitive value chains (NSVCs) (FAO., 2017a,b; Uccello et al., 2017) ${ }^{3}$. These

\footnotetext{
${ }^{3}$ Identifying Opportunities For Nutrition-Sensitive Value-Chain Interventions. IFPRI. Available online at: http://www.ifpri.org/blog/identifying-opportunitiesnutrition-sensitive-value-chain-interventions. (accessed March 17, 2019).
}

aim to enhance supply and demand for nutritious foods while sustainably adding nutritional value at critical chain stages (FAO., 2017b). This framework examines links between nutrition issues in target populations and constraints in supply and demand for foods that may address these problems (de la Peña and Garrett, 2018). Ultimately, NSVCs deployed at the local level improve availability, affordability, quality, and acceptability of nutritious food.

Many initiatives throughout Minnesota aim to improve access to healthful, sustainable, affordable foods, and these efforts could align with a NSVC framework. For example, the Minnesota Food Charter, developed by multi-disciplinary, multi-sector food leaders launched in 2014 to provide a roadmap to guide policymakers and community leaders in providing Minnesotans with access to safe, equitable, affordable, healthful foods ${ }^{4}$. The Charter also formed a network connecting key players working in food equity and sustainability like Second Harvest Heartland, the Good Acre, and the Regional Sustainable Development Partnerships (RSDP).

Second Harvest Heartland and The Good Acre improve access to healthful foods and strengthen local agriculture in the Twin Cities through community partnerships. Second Harvest Heartland recovers food throughout the supply chain, which it then distributes to food pantries and other community partners throughout Minneapolis and St. Paul ${ }^{5}$. They also house a hydroponic farm that facilitates hands-on participation in sustainable farming while supplying fresh produce year-round ${ }^{6}$. The Good Acre, a food hub in Falcon Heights, connects farmers, producers, and communities throughout the local food system. They operate a wholesale program that provides schools with fresh produce and implement culinary and agriculture programs to ensure the integrity and safety of agricultural products ${ }^{7,8}$.

Several initiatives connect and reconnect indigenous cultures to the food system. The Seeds of Native Health Campaign for Indigenous Nutrition, led by the Shakopee Mdewakanton Sioux Community, works to restore food sovereignty for Minnesota indigenous communities. The Shakopee Mdewakanton Sioux Community hosts an annual Conference on Native American Nutrition, which convenes tribal officials, researchers, practitioners and others to discuss indigenous and academic knowledge regarding Native health and food ${ }^{9}$. Dream of Wild Health is another group reconnecting indigenous communities with their cultural roots through food

\footnotetext{
${ }^{4}$ What is the Minnesota Food Charter? Available online at: http://mnfoodcharter. com/the-charter/what-is-the-minnesota-food-charter/ (accessed July 6, 2019).

${ }^{5}$ About Us | Second Harvest Heartland. Available online at: http://www.2harvest. org/about_us/ (accessed July 7, 2019).

${ }^{6}$ Our Farm | Second Harvest Heartland. Available online at: http://www. 2harvest.org/who--how-we-help/services-and-programs/programs/ourfarm. html (accessed July 7, 2019).

${ }^{7}$ The Good Acre Annual Report. Falcon Heights: The Good Acre. p. 1-14.

${ }^{8}$ Who We Are. The Good Acre. Available Online at: https://thegoodacre.org/whowe-are/ (accessed July 7, 2019).

${ }^{9} 2019$ Native nutrition conference. Seeds of Native Health. Available online at: https://seedsofnativehealth.org/conference/ (accessed July 7, 2019).
} 


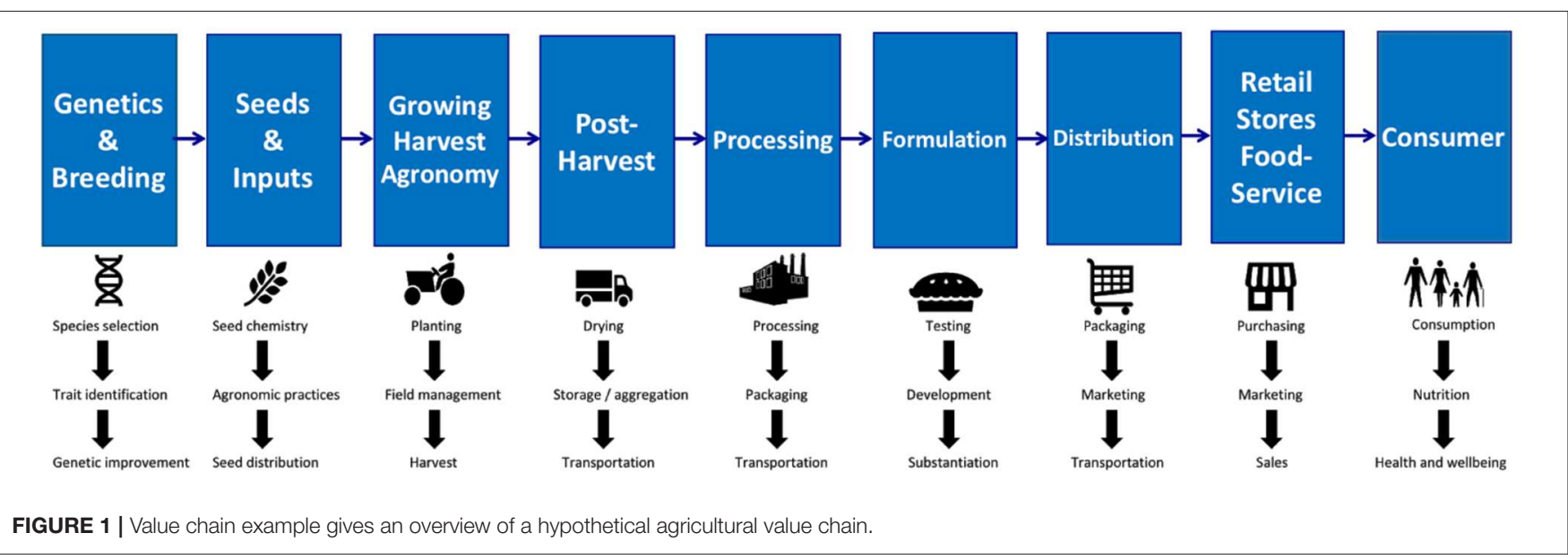

via youth programs, CSAs, food demonstrations, a 10-acre farm, and a community garden ${ }^{10}$.

The RSDP is an Extension program aiming to improve agricultural sustainability while developing markets for local products $^{11}$. The group coordinates with programs like the Forever Green Initiative (FGI), which works to improve biodiversity and regenerative agriculture by incorporating new crops in conventional crop rotations (jewet006, 2016). The RSDP also works with groups facilitating entrepreneurial projects, like Grow North $\mathrm{MN}^{12}$. Each of these initiatives could be leveraged to develop NSVCs.

\section{PART 4 - NUTRITION SENSITIVE VALUE CHAINS: AN OPPORTUNITY FOR IMPROVED HEALTH}

Developing sustainable NSVCs could provide more Minnesotans with access to foods that support human and environmental health. NSVCs provide a framework to improve nutrition in Minnesota by connecting, coordinating, and supporting groups working on agriculture, food, and health. The University of Minnesota interfaces with upstream and downstream value chain actors as well as other value chain influences (Figure 2). Thus, it can play a key role in facilitating NSVCs.

The University of Minnesota houses many departments and research platforms that train the next generation of value chain actors. These departments can conduct research on individual parts of the value chain in a systemic and coordinated manner, as illustrated in Figure 3. For example, the Department of Agronomy and Plant Genetics plays a key role in improving crops and developing sustainable farming practices. The Department of Bioproducts and Bio Systems Engineering develops methods for

\footnotetext{
${ }^{10}$ Programs. Dream of Wild Health. Available online at: https://dreamofwildhealth. org/programs (accessed July 8, 2019).

${ }^{11}$ RSDP projects | UMN Extension. Available online at: https://extension.umn.edu/ regional-partnerships/rsdp-projects. (accessed July 14, 2019).

${ }^{12}$ Resource Navigator Database. (Grow North, MN). Available online at: https:// carlsonschool.umn.edu/grownorth/about/ourmission. (accessed July 8, 2019).
}

processing raw materials into food ingredients. The Department of Food Science and Nutrition evaluates end-use, sensory and nutritional qualities, and safety of raw materials and finished products. The Department of Applied Economics and the Carlson School of Business evaluate the production and supply chain economics. The School of Public Health can evaluate the broader health implications of production and consumption while the Institute on the Environment can assess sustainability impacts. Taken together, these departments represent nearly the entire field-to-consumer continuum, and they can collaborate with local groups to develop NSVCs.

The University of Minnesota is well-positioned to engage local groups working on individual parts of the value chain, which could improve food systems through enhanced coordination and collaboration. For example, RSDP, Grow North MN, and FGI develop new crop enterprises and cultivate local food entrepreneurship. These groups may benefit from coordinating with groups that work downstream in the value chain like Second Harvest and the Good Acre, who traditionally focus on supplying foods to citizens. Agricultural training offered through the Good Acre and Second Harvest may benefit from the networks and knowledge systems offered through FGI, RSDP, and Grow North MN. Bridging these groups clearly aligns with the mission of university extension programs by offering training opportunities to local communities. These relationships can advance mutual research goals for many value chain actors. Table 2 highlights potential collaborative relationships between value chain stakeholders and University of Minnesota Departments.

Given the industry and cooperative presence in Minnesota, there are ample opportunities to connect mid-stream actors (e.g., processing, storage, and logistics) to upstream (e.g., FGI, RSDP) and downstream (e.g., Good Acre, Second Harvest) entities, along with university departments (Table 2). Currently, few nutrition-focused efforts engage this tier of the value chain, yet it plays a major role in influencing consumption (Stuckler and Nestle, 2012; Willett et al., 2019). Efforts occurring at this part of the value chain could provide an impactful new opportunity for university engagement. 


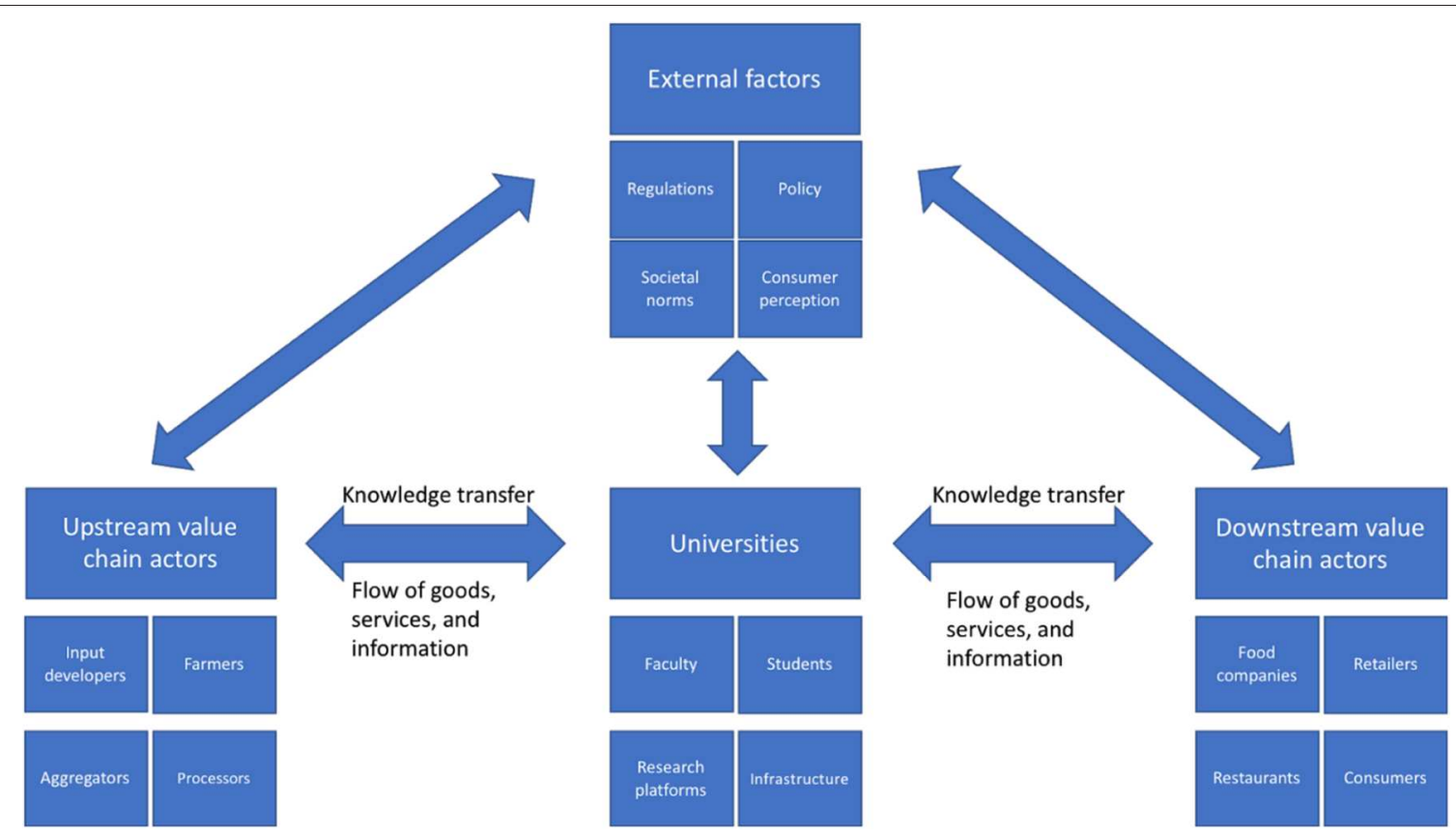

FIGURE 2 | Relationship between value chain actors and the University of Minnesota shows the reciprocal relationships between universities and value chain actors and influencers.

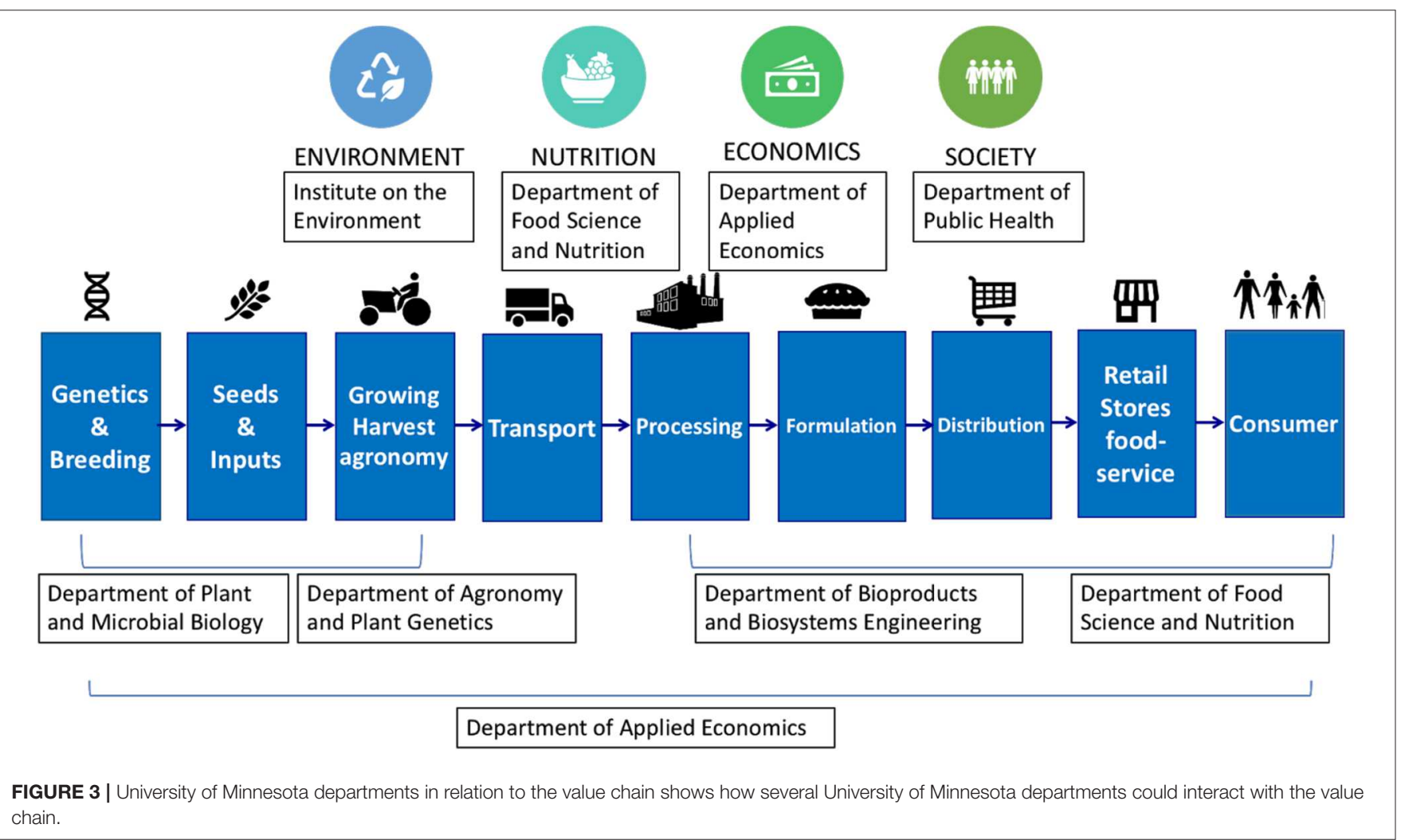

Empowering community members to take leading roles in developing NSVCs is imperative to ensure key issues are prioritized and solutions are culturally appropriate (Uccello et al., 2017). Creating safe environments for community groups (e.g., Dream of Wild Health) to equitably collaborate with other firms interested in developing NSVCs (e.g., 
TABLE 2 | Recommendation of potential collaborations between Value chain actors and influencers, and the University of Minnesota.

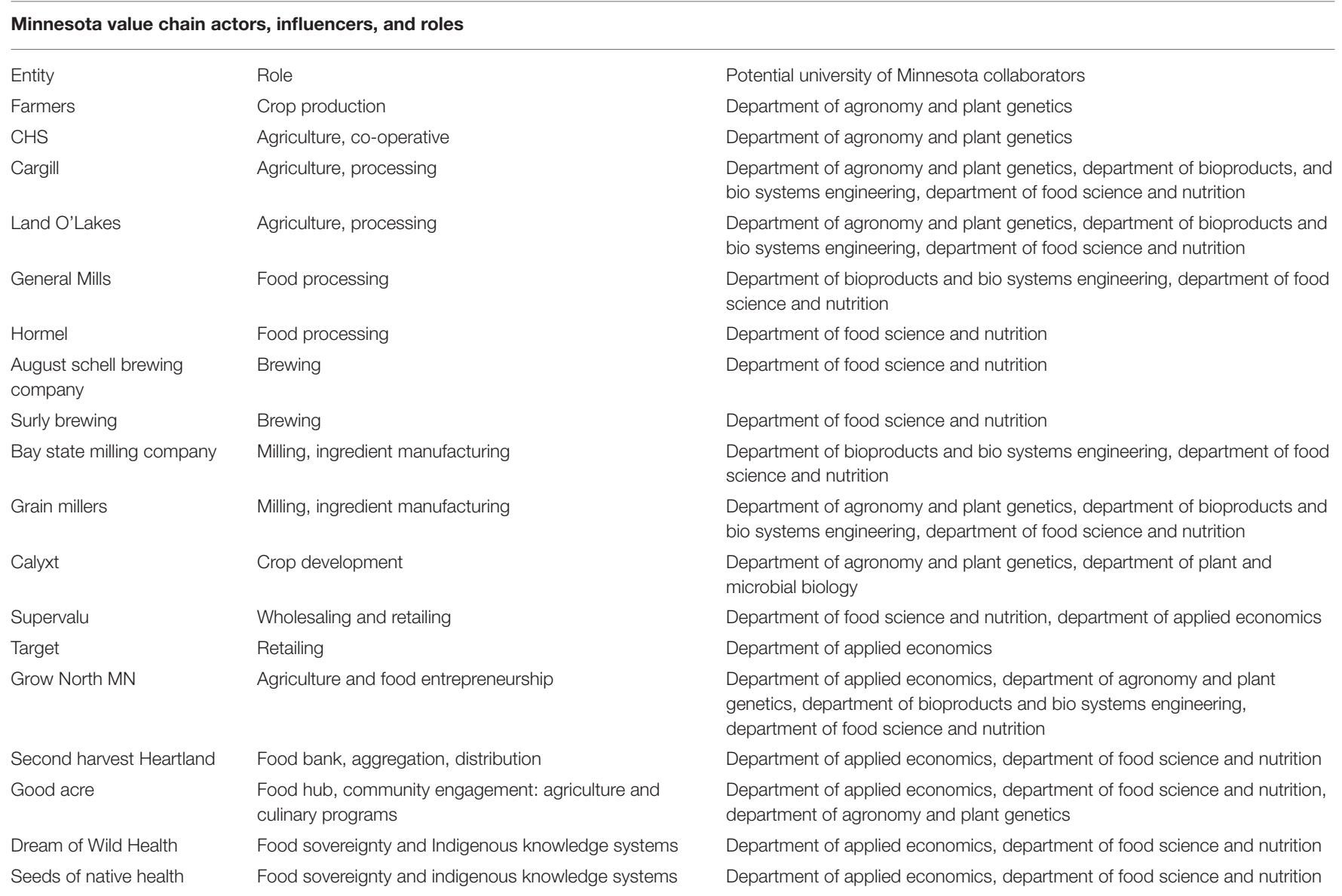

This is a non-comprehensive overview.

FGI, RSDP, Good Acre, and Second Harvest) could yield unprecedented nutrition outcomes. These engagements could be brokered through CBPAR models, whereby community stakeholders identify critical health issues and collaborate with university and supply chain stakeholders to develop NSVCs that address these problems. Land grant universities offer a mechanism to align and unite across sectors and disciplines to sustainably develop NSVCs while fulfilling their land grant mission. This integrative approach can improve the relevancy and impact of the nutrition discipline while creating more sustainable, healthful, equitable, economically resilient food systems.

\section{CONCLUSION}

Food and agriculture professionals must provide the growing population healthful diets that support resilient food systems. Global initiatives provide goals and recommendations for more sustainable diets and food production (FAO., 2017a; Willett et al., 2019). Developing sustainable NSVCs could achieve these goals (FAO., 2017b; Uccello et al., 2017; de la Peña and Garrett, 2018). Land grant universities can play a key role in assisting local efforts to develop NSVCs to ensure food security while fulfilling their mission of research, outreach, and education. Actively participating in systems approaches is crucial for this process. The medical sector and STEM fields provide models for integrating systems approaches into research and training (Choi and Pak, 2006, 2007; Stroud et al., 2017; Fowler et al., 2019). Institutional processes that disincentivize multiple-disciplinary collaborations must be overcome to facilitate systems approaches. Perhaps adjusting these processes to emphasize more multiple disciplinary, systems-based work could stimulate food systems approaches and improve health and environmental outcomes. Creating processes for local communities to actively participate in the development of NSVCs is crucial. Building reciprocal relationships through CBPAR can help to integrate communities into this process. Given its strong ties to local food systems and global food producers along with its diverse institutional expertise, the University of Minnesota is well-positioned to play a key role in developing models and frameworks supporting the development of NSVCs. This integrative, systematic process can improve the efficacy of nutrition research by intimately engaging across the supply chain, thus effectively translating research into practical application. Coordinated, systems-approaches, rather than reductionist, single disciplinary approaches, are essential to 
address the complex challenges throughout 21 st century food systems. Universities, industry, and policy makers can strive together to incentivize these systemic processes, through shared value and common purpose to ensure the persistence of human and planetary health.

\section{REFERENCES}

Afshin, A., Micha, R., Khatibzadeh, S., and Mozaffarian, D. (2014). Consumption of nuts and legumes and risk of incident ischemic heart disease, stroke, and diabetes: a systematic review and meta-analysis. Am. J. Clin. Nutr. 100, 278-288. doi: 10.3945/ajcn.113.076901

Aleksandrowicz, L., Green, R., Joy, E. J. M., Smith, P., and Haines, A. (2016). The impacts of dietary change on greenhouse gas emissions, land use, water use, and health: a systematic review. PLOS ONE 11:e0165797. doi: 10.1371/journal.pone.0165797

Andrieu, E., Darmon, N., and Drewnowski, A. (2006). Short communication lowcost diets : more energy, fewer nutrients. Eur. J. Clin. Nutr. 60, 434-436. doi: $10.1038 /$ sj.ejcn.1602331

Association of Public and Land-Grant Universities [APLU]. (2012). The LandGrant Tradition. Available Online at: https://www.aplu.org/library/the-landgrant-tradition/file (accessed October 24, 2019).

Aune, D., Giovannucci, E., Boffetta, P., Fadnes, L. T., Keum, N., Norat, T., et al. (2017). Fruit and vegetable intake and the risk of cardiovascular disease, total cancer and all-cause mortality-a systematic review and doseresponse meta-analysis of prospective studies. Int. J. Epidemiol. 46:1029-1056. doi: 10.1093/ije/dyw319

Aune, D., Keum, N., Giovannucci, E., Fadnes, L. T., Boffetta, P., Greenwood, D. C., et al. (2016a). Whole grain consumption and risk of cardiovascular disease, cancer, and all cause and cause specific mortality: systematic review and dose-response meta-analysis of prospective studies. BMJ 353:i2716. doi: 10.1136/bmj.i2716

Aune, D., Keum, N., Giovannucci, E., Fadnes, L. T., Boffetta, P., Greenwood, D. C., et al. (2016b). Nut consumption and risk of cardiovascular disease, total cancer, all-cause and cause-specific mortality: a systematic review and dose-response meta-analysis of prospective studies. BMC Med. 14:207. doi: 10.1186/s12916-016-0730-3

Barbier, E. B., and Burgess, J. C. (2017). The sustainable development goals and the systems approach to sustainability. Econ. Open-Access Open Assess. E-J. 11, 1-22. doi: 10.5018/economics-ejournal.ja.2 017-28

Bernstein, A. M., Sun, Q., Hu, F. B., Stampfer, M. J., Manson, J. E., and Willett, W. C. (2010). Major dietary protein sources and risk of coronary heart disease in women. Circulation 122, 876-883. doi: 10.1161/CIRCULATIONAHA.109.915165

Bertoia, M. L., Mukamal, K. J., Cahill, L. E., Hou, T., Ludwig, D. S., Mozaffarian, D., et al. (2015). Changes in intake of fruits and vegetables and weight change in united states men and women followed for up to 24 years: analysis from three prospective cohort studies. PLoS Med. 12:e1001878. doi: 10.1371/journal.pmed.1001878

Boland, M., Cooper, B., and White, J. M. (2016). Making sustainability tangible: land o'lakes and the dairy supply chain. Am. J. Agric. Econ. 98, 648-657. doi: 10.1093/ajae/aav062

Campbell, B. (2010). Applying knowledge to generate action: a community-based knowledge translation framework: J. Contin. Educ. Health Prof. 30, 65-71. doi: 10.1002/chp.20058

Chen, G.-C., Lv, D.-B., Pang, Z., and Liu, Q.-F. (2013). Red and processed meat consumption and risk of stroke: a meta-analysis of prospective cohort studies. Eur. J. Clin. Nutr. 67, 91-95. doi: 10.1038/ejcn.2012.180

Choi, B. C. K., and Pak, A. W. P. (2006). Multidisciplinarity, interdisciplinarity and transdisciplinarity in health research, services, education and policy: 1. definitions, objectives, and evidence of effectiveness. Clin. Invest. Med. 29, 351-364.

Choi, B. C. K., and Pak, A. W. P. (2007). Multidisciplinarity, interdisciplinarity, and transdisciplinarity in health research, services, education and policy: 2 .

\section{AUTHOR CONTRIBUTIONS}

KR and LM conceived the idea for the manuscript. KR wrote the manuscript, and both authors edited and expanded the manuscript.

Promotors, barriers, and strategies of enhancement. Clin. Invest. Med. 30:224. doi: 10.25011/cim.v30i6.2950

Clark, M., Hill, J., and Tilman, D. (2018). The Diet, Health, and Environment. Trilemma. 29, 109-134. doi: 10.1146/annurev-environ-102017-025957

Clark, M., and Tilman, D. (2017). Comparative analysis of environmental impacts of agricultural production systems, agricultural input efficiency, and food choice. Environ. Res. Lett. 12:064016. doi: 10.1088/1748-9326/aa6cd5

Clune, S., Crossin, E., and Verghese, K. (2017). Systematic review of greenhouse gas emissions for different fresh food categories. J. Clean. Prod. 140, 766-783. doi: 10.1016/j.jclepro.2016.04.082

de la Peña, I., and Garrett, J. (2018). Nutrition-sensitive value chains: a guide for project design. Int. Fund Agr. Dev. 1, 1-85. Available online at: https://www. ifad.org/documents/38714170/40804965/GFPD+Nutrition-sensitive+value+ chains+VOL.1/5177a3c0-a148-4b1f-8fff-967a42f51ce8 (accessed December 7, 2019)

Drewnowski, A. (2018). Measures and metrics of sustainable diets with a focus on milk, yogurt, and dairy products. Nutr. Rev. 76, 21-28. doi: 10.1093/nutrit/nux063

FAO. (2017a). FAO and the 17 Sustainable Development Goals. Rome: Food and Agriculture Organization of the United Nations. Available online at: https:// sustainabledevelopment.un.org/content/documents/2205FAO\%20and\%20the \%2017\%20SDGs.pdf (accessed June 7, 2019).

FAO. (2017b). How can Value Chains be Shaped to Improve Nutrition? Available Online at: http://www.fao.org/3/a-br703e.pdf (accessed July 8, 2019).

Feskens, E. J. M., Sluik, D., and van Woudenbergh, G. J. (2013). Meat consumption, diabetes, and its complications. Curr. Diabetes Rep. 13, 298-306. doi: 10.1007/s11892-013-0365-0

Fowler, W. C., Ting, J. M., Meng, S., Li, L., and Tirrell, M. V. (2019). Integrating systems thinking into teaching emerging technologies. J. Chem. Educ. 96, 2805-2813. doi: 10.1021/acs.jchemed.9b00280

Gomez, M., and Barrett, C. (2013). "Special section: food systems and the triple burden of malnutrition," in Food Policy 42, eds M, Gomez., C, Barrett (Ithaca, NY: Charles, H. Dyson School of Applied Economics and Management, Cornell University), 115-163. doi: 10.1016/j.foodpol.2013.06.009

Graham, I. D., Logan, J., Harrison, M. B., Straus, S. E., Tetroe, J., Caswell, W., et al. (2006). Lost in knowledge translation: time for a map? J. Contin. Educ. Health Prof. 26, 13-24. doi: 10.1002/chp.47

Hallström, E., Carlsson-Kanyama, A., and Börjesson, P. (2015). Environmental impact of dietary change: a systematic review. J. Clean. Prod. 91, 1-11. doi: $10.1016 /$ j.jclepro.2014.12.008

Hassel, C. A. (2014). Reconsidering nutrition science: critical reflection with a cultural lens. Nutr. J. 13:42. doi: 10.1186/1475-2891-13-42

Hassel, C. A., Tamang, A. L., Foushee, L., and Bull, R. B. H. (2019). Decolonizing nutrition science. Curr. Dev. Nutr. 3, 3-11. doi: 10.1093/cdn/nzy095

Huang, T. T., Drewnowski, A., Kumanyika, S., and Glass, T. (2009). A systemsoriented multilevel framework for addressing obesity in the 21st century. Prev. Chronic Dis. 6, A82.

Hung, H. C., Joshipura, K. J., Jiang, R., Hu, F. B., Hunter, D., Smith-Warner, S. A., et al. (2004). Fruit and vegetable intake and risk of major chronic disease. JNCI J. Natl. Cancer Inst. 96, 1577-1584. doi: 10.1093/jnci/djh296

Ingram, J., Ajates, R., Arnall, A., Blake, L., Borrelli, R., Collier, R., et al. (2020). A future workforce of food-system analysts. Nat. Food 1, 9-10. doi: 10.1038/s43016-019-0003-3

jewet006 (2016). Vision. Forever Green. Available Online at: https://www. forevergreen.umn.edu/about/vision (accessed July 6, 2019).

Korczak, R., Hauge, D., Maschoff, B., Marquqart, L., Jacques, P., Menon, R., et al. (2015). "Grains and Health," in Encyclopedia of Food Grains. Vol 2, 2nd ed, (Cambridge, MA: Academic Press), 63-71. doi: 10.1016/B978-0-12-394437-5.00067-X 
Krebs-Smith, S. M., Reedy, J., and Bosire, C. (2010). Healthfulness of the U.S. Food supply. Am. J. Prev. Med. 38, 472-477. doi: 10.1016/j.amepre.2010.01.016

Lipsitz, L. A. (2012). Understanding health care as a complex system: the foundation for unintended consequences. JAMA 308:243. doi: 10.1001/jama.2012.7551

Miller, P. E., Reedy, J., Kirkpatrick, S. I., and Krebs-Smith, S. M. (2015). The united states food supply is not consistent with dietary guidance: evidence from an evaluation using the healthy eating index-2010. J. Acad. Nutr. Diet. 115, 95-100. doi: 10.1016/j.jand.2014.08.030

Minkler, M. (2005). Community-based research partnerships: challenges and opportunities. J. Urban Health: Bull. NY. Acad. Med. 82, ii3-ii12. doi: 10.1093/jurban/jti034

Minnesota Department of Health (2019a). Food Access - Access to Health and Afordable Food. St. Paul, MN: Minnesota Department of Health.

Minnesota Department of Health (2019b). Adult Obesity in Minnesota Data Brief. St. Paul, MN: Minnesota Department of Health. p. 4.

Monsivais, P., and Drewnowsky, A. (2010). Lower-energy-density diets are associated with higher monetary costs per kilocalorie and are consumed by women of higher socioeconomic status. J. Am. Diet Assoc. 109, 814-822. doi: 10.1016/j.jada.2009.02.002

Muraki, I., Imamura, F., Manson, J. E., Hu, F. B., Willett, W. C., van Dam, R. M., et al. (2013). Fruit consumption and risk of type 2 diabetes: results from three prospective longitudinal cohort studies. BMJ 347, f5001-f5001. doi: 10.1136/bmj.f5001

Nelson, M. E., Hamm, M. W., Hu, F. B., Abrams, S. A., and Griffin, T. S. (2016). Alignment of healthy dietary patterns and environmental sustainability: a systematic review. Adv. Nutr. Int. Rev. J. 7, 1005-1025. doi: 10.3945/an.116.012567

Ogden, C. L., Fakhouri, T. H., Carroll, M. D., Hales, C. M., and Fryar, C. D. (2017). Prevalence of obesity among adults, by household income and education United States, 2011 - 2014. Center Dis. Control Prev. Morb. Mortal. Weekly Rep. 66, 1369-1373. doi: 10.15585/mmwr.mm6650al

Orlich, M. J., Singh, P. N., Sabaté, J., Jaceldo-Siegl, K., Fan, J., Knutsen, S., et al. (2013). Vegetarian dietary patterns and mortality in adventist health study 2. JAMA Intern. Med. 173:1230. doi: 10.1001/jamainternmed.2013.6473

Pan, A., Sun, Q., Bernstein, A. M., Schulze, M. B., Manson, J. E., Stampfer, M. J., et al. (2012). Red meat consumption and mortality: results from 2 prospective cohort studies. Arch. Intern. Med. 172:555. doi: 10.1001/archinternmed.2011.2287

Parker, E. D., Liu, S., Van Horn, L., Tinker, L. F., Shikany, J. M., Eaton, C. B., et al. (2013). The association of whole grain consumption with incident type 2 diabetes: the Women's Health Initiative Observational Study. Ann. Epidemiol. 23, 321-327. doi: 10.1016/j.annepidem.2013. 03.010

Rausch, E. J., Mattessich, P. W., and Research, W. (2016). Healthy food access: a view of the landscape in minnesota and lessons learned from healthy food financing initiatives. 54. Available online at: https://www.wilder.org/sites/ default/files/imports/Healthy\%20Food\%20Access\%20Study_Final\%20Report_ April\%202016.pdf (accessed September 3, 2020).

Ribeiro, P. F., Santos, J. L., Santana, J., Reino, L., Beja, P., and Moreira, F. (2016). An applied farming systems approach to infer conservation-relevant agricultural practices for agri-environment policy design. Land Use Policy 58, 165-172. doi: 10.1016/j.landusepol.2016.07.018

Satija, A., Bhupathiraju, S. N., Rimm, E. B., Spiegelman, D., Chiuve, S. E., Borgi, L., et al. (2016). Plant-based dietary patterns and incidence of type 2 diabetes in US men and women: results from three prospective cohort studies. PLoS Med. 13:e1002039. doi: 10.1371/journal.pmed.1002039
Satija, A., Bhupathiraju, S. N., Spiegelman, D., Chiuve, S. E., Manson, J. E., Willett, W., et al. (2017). Healthful and unhealthful plant-based diets and the risk of coronary heart disease in U.S. Adults J. Am. Coll. Cardiol. 70, 411-422. doi: $10.1016 /$ j.jacc.2017.05.047

Sehgal, N. L., Fox, M., Vidyarthi, A. R., Sharpe, B. A., Gearhart, S., Bookwalter, T., et al. (2008). A multidisciplinary teamwork training program: the triad for optimal patient safety (TOPS) experience. J. Gen. Intern. Med. 23, 2053-2057. doi: 10.1007/s11606-008-0793-8

Stroud, J., Jenkins, K., Bhandary, S., and Papadimos, T. (2017). Putting the pieces together: the role of multidisciplinary simulation in medical education. Int. J. Acad. Med. 3, 104-109. doi: 10.4103/IJAM.IJAM_44_17

Stuckler, D., and Nestle, M. (2012). Big food, food systems, and global health. PLoS Med. 9:e1001242. doi: 10.1371/journal.pmed.1001242

Tilman, D., Balzer, C., Hill, J., and Befort, B. L. (2011). Global food demand and the sustainable intensification of agriculture. Proc. Natl. Acad. Sci. U.S.A. 108, 20260-20264. doi: 10.1073/pnas.1116437108

Tu, C., Suweis, S., and D'Odorico, P. (2019). Impact of globalization on the resilience and sustainability of natural resources. Nat. Sust. 2, 283-289. doi: 10.1038/s41893-019-0260-z

Uccello, E., Kauffmann, D., Calo, M., and Streissel, M. (2017). Food and Agriculture Organization of the United Nations. Nutrition-Sensitive Agriculture and Food Systems in Practice. Options for Intervention (Rome).

US Department of Agriculture and US Department of Health and Human Services (2000). 2015-2020 Dietary Guidelines for Americans. 8th Edition. Washington, DC. Available Online at: http://health.gov/dietaryguidelines/2015/guidelines/ (accessed December 7, 2019).

Wallerstein, N., and Duran, B. (2010). Community-based participatory research contributions to intervention research: the intersection of science and practice to improve health equity. Am. J. Public Health 100, S40-S46. doi: 10.2105/AJPH.2009.184036

Wallerstein, N. B., and Duran, B. (2006). Using community-based participatory research to address health disparities. Health Promot. Pract. 7, 312-323. doi: $10.1177 / 1524839906289376$

Weaver, T. E. (2008). Enhancing multiple disciplinary teamwork. Nurs. Outlook 56, 108-114.e2. doi: 10.1016/j.outlook.2008.03.013

Willett, W., Rockström, J., Loken, B., Springmann, M., Lang, T., Vermeulen, S., et al. (2019). Food in the anthropocene: the EAT-lancet commission on healthy diets from sustainable food systems. Lancet 393, 447-492. doi: 10.1016/S0140-6736(18)31788-4

Wognum, P. M., Bremmers, H., Trienekens, J. H., van der Vorst, J. G. A. J., and Bloemhof, J. M. (2011). Systems for sustainability and transparency of food supply chains - current status and challenges. Adv. Eng. Inform. 25, 65-76. doi: 10.1016/j.aei.2010.06.001

Ye, S. (2019). Minnesota Agricultural Profile. Available Online at: https://www. mda.state.mn.us/sites/default/files/inline-files/mnagprofile2019.pdf (accessed March 20, 2020).

Conflict of Interest: The authors declare that the research was conducted in the absence of any commercial or financial relationships that could be construed as a potential conflict of interest.

Copyright $\odot 2020$ Ringling and Marquart. This is an open-access article distributed under the terms of the Creative Commons Attribution License (CC BY). The use, distribution or reproduction in other forums is permitted, provided the original author(s) and the copyright owner(s) are credited and that the original publication in this journal is cited, in accordance with accepted academic practice. No use, distribution or reproduction is permitted which does not comply with these terms. 